\title{
RESEARCH PAPER \\ INTERNATIONAL FINANCIAL REPORTING STANDARDS AND FINANCIAL REPORTING QUALITY IN NIGERIA
}

\author{
A. Aderin and J. P. Otakefe \\ Department of Accounting, Faculty of Management Sciences, \\ University of Benin, Benin City, Edo State, Nigeria
}

\begin{abstract}
The study examines the impact of the adoption of International Financial Reporting Standards (IFRS) on the quality of financial reporting in Nigeria. The study utilises a period based approach to analyse changes in the degree of financial reporting quality (FRQ) that hinges on three proxies: Value Relevance, Earnings Quality and Earnings Management. Three models were developed to capture each proxy, and the models were analysed using regression analysis to evaluate the $R^{2}$ statistics; which captured the direction of change in the reporting quality. The results showed that financial reporting quality increased after the adoption of the IFRS for all the relevant proxies. The study concludes that the adoption of IFRS to enhance financial reporting quality while reducing the probability of earnings management practices could be beneficial in the long run to the Nigerian financial landscape.
\end{abstract}

Keywords: Reporting Standards, Value, Relevance, Earnings, Management

\section{INTRODUCTION}

The need for uniformity of financial statements across borders led many economies to adopt the International Financial Reporting Standards (IFRS). International Financial Reporting Standards are issued by the International Accounting Standards Board (IASB), an independent organisation registered in the United States of America (USA) but based in London, United Kingdom. IASB issues financial reporting standards that ideally would apply equally to financial reporting by public interest entities world- wide. In Nigeria, adoption of IFRS was launched in September 2010, by the Honorable Minister, Federal Ministry of Commerce and Industry, Senator Jubril Martins-kuye. The adoption was organised such that all stakeholders would use the IFRS by January 2014 (Madawaki, 2012).

The IASB in its objectives and preamble, expects the beneficial effects from IFRS adoption to include transparency, improved accounting quality and reduced cost of capital. Despite the 
74

Aderin and Otakefe

perceived benefits of the implementation of the IFRS, the adoption is wrought with challenges. These benefits and challenges could lead to favourable/adverse implications at both the micro and macro-economic levels. It becomes an interesting source for stakeholders to ascertain whether the standards are achieving their basic tenets and objectives. For instance IFRS is perceived to engender improvements in financial reporting quality due to increased stringency in its usage and application, and one wonders if this is really the case. It is also argued that implementing IFRS enhances earnings quality by reducing information asymmetry, decreasing earnings management, providing more value relevant financial information to investors/shareholders, and decreasing cost of capital.

Based on these assumptions, the study applied accounting quality measures; value relevance, earnings quality, and earnings management to find out whether the adoption of IFRS has led to improvements in the reporting quality of companies listed on the Nigerian Stock Exchange.

\section{LITERATURE REVIEW}

Previous research on the subject matter has produced differing results on the impact of IFRS on financial reporting quality. The effect of adoption of IFRS on financial reporting quality could vary across different countries. The mixed findings documented in earlier studies can be explained by countries' institutional structures. Many studies argue that developing and transitional economies still have ineffective institutions and infrastructure; though their capital market may be developing fast. Nigeria is one of the largest developing countries in Africa, characterised by concentrated ownership structures, weak legal systems and highly politicized institutional arrangements. These peculiarities could inform a level of variance in the results obtained in the study.

IFRS adoption and value relevance

IFRS adoption is generally encouraged be- cause it is perceived to promote fair value accounting which inadvertently weakens the link between taxation and accounting rules, hence, it is expected that earnings and book value would automatically become more value relevant. However, extant literature on the implications of IFRS adoption on the value relevance of financial information has presented contentious views and results.

The empirical works of Muller (2014), Kargin (2013), Palea (2013), Lin et al. (2012), Karampinis and Hevas (2009) and Paglietti (2009) investigated the association between IFRS adoption and value relevance and they indicated that value relevance of accounting information improved during the post-IFRS period. The studies of Garanina and Kormiltseva (2013) and Outa (2011) however negated the positive effect of IFRS adoption on the value relevance of accounting information.

\section{IFRS adoption and earnings quality}

Ismail et al. (2013), Sellami and Fakhfakh (2013), Assidi and Omri (2012) and Sun et al. (2011) noticed increases in earnings quality in the post IFRS periods. However, the works of Ames (2013), Nullah (2013) and Hoque et al. (2012) showed that earnings portrayed lower persistency and predictability after IFRS adoption. Their studies generally stipulate that IFRS adoption per se does not lead to increased quality of earnings.

\section{IFRS adoption and earnings management}

The introduction of the IFRS has reduced the flexibility of accounting choices in the preparation of financial statements. The more stringent measures in the application of IFRS therefore led many to believe that the use of the standards would inadvertently lead to decreases in the propensity for earnings management. Also, the adoption of the standards is perceived to enhance the efficiency of the board of directors (due to the higher level of disclosure and transparency inherent in IFRS) which puts more constrain on them to monitor the extent of earnings management practices. 
Athanasios et al. (2013), Dimitropoulos et al. (2013) and Iatridis and Rouvolis (2010) examined the impact of IFRS adoption on the quality of accounting information within the Greek accounting setting. They found convincing evidence that the implementation of IFRS contributed to less earnings management compared to the local accounting standards.

Liu et al. (2011) examined the impact of IFRS on accounting quality in China. Their empirical results generally indicate that accounting quality improved with decreased earnings management and increased value relevance of accounting measures. However Ahmed et al. (2013) in their meta-analysis found that discretionary accruals did not reduce post-IFRS adoption. Doukakis (2013) showed that IFRS adoption had no significant impact on either real or accrual based earnings management practices while the work of Jeanjean and Stolowy (2008) indicated that the pervasiveness of earnings management did not decline, but rather increased after the adoption of IFRS in France.

\section{METHODOLOGY}

Data for the study are gathered from secondary sources. The justification for the use of secondary source of data is inherent in the nature and measurement of the variables to be utilised in the study. Data is gathered from the annual reports and financial statements of 23 companies listed under the agriculture, conglomerate, construction and healthcare sectors of the Nigerian Stock Exchange for a period of 4 years; pre and post IFRS adoption. The hypotheses utilised in the study are given as follows:

Ho $_{1}$ : There is no significant relationship between IFRS adoption and the value relevance of financial information.

$\mathrm{Ho}_{2}$ : There is no significant relationship between IFRS adoption and earnings quality in Nigeria.

$\mathrm{Ho}_{3}$ : There is no significant relationship between IFRS adoption and earnings management in Nigeria.

The study utilises three regression models to capture the changes in each of the variables over the given time spectrum. Model 1 is used to capture the proxy for value relevance, measured by market value of the firm. Model 2 is used to capture the proxy for earnings quality; measured by accrual quality, while model 3 is used to capture the proxy for earnings management; represented by discretionary accruals. The models are given as follows:

Model 1: (Pre-IFRS)

$$
\mathrm{MV}=\beta_{0}+\beta_{1} \mathrm{PAT}+\beta_{2} \mathrm{BVE}+\beta_{3} \mathrm{NOSH}+\mathrm{U}_{\mathrm{t}} .
$$

(Post-IFRS)

$$
\mathrm{MV}=\beta_{0}+\beta_{1} \mathrm{PAT}+\beta_{2} \mathrm{BVE}+\beta_{3} \mathrm{NOSH}+\mathrm{U}_{\mathrm{t}} .
$$

Model 2: (Pre-IFRS)

$$
\mathrm{ACCR}=\beta_{0}+\beta_{1} \mathrm{OCF}+\beta_{2} \delta \mathrm{REV}+\beta_{3} \mathrm{PPE}+\mathrm{U}_{\mathrm{t}} .
$$

(Post-IFRS)

$$
\mathrm{ACCR}=\beta_{0}+\beta_{1} \mathrm{OCF}+\beta_{2} \delta \mathrm{REV}+\beta_{3} \mathrm{PPE}+\mathrm{U}_{\mathrm{t}} .
$$

Model 3: (Pre-IFRS)

$$
\begin{aligned}
& \mathrm{DACC}=\beta_{0}+\beta_{1} \mathrm{REV}+\beta_{2} \mathrm{PPE}+\beta_{3} \mathrm{WC}+\beta_{4} \mathrm{EBIT}+\mathrm{U}_{\mathrm{t}} . \\
& \mathrm{DACC}=\beta_{0}+\beta_{1} \mathrm{REV}+\beta_{2} \mathrm{PPE}+\beta_{3} \mathrm{WC}+\beta_{4} \mathrm{EBIT}+\mathrm{U}_{\mathrm{t}} .
\end{aligned}
$$

(Post-IFRS)

Where

MV $=$ Market Value

PAT $=$ Profit after Tax for Continuing Operations

$\mathrm{BVE}=$ Book Value of Equity

NOSH $=$ Number of Ordinary Shares

ACCR $=$ Total Accruals
OCF $=$ Operating Cash Flow

$\delta \mathrm{REV}=$ Change in Revenue PPE $=$ Property, Plant and Equipment DACC $=$ Discretionary Accruals $\mathrm{WC}=$ Working Capital $\mathrm{EBIT}=$ Profit before Interest and Tax 


\section{Aderin and Otakefe}

The models are adapted from the work of $\mathrm{He} e t$ al. (2009), but are modified to suit the objectives of the study. The data is analysed using the ordinary least square (OLS) regression methodology. Each model is analysed for each of the years covered by the study and for each of the variables under consideration.

The adjusted $\boldsymbol{R}^{2}$ obtained from the regression results is used to determine the trend of the financial reporting proxies. Increases in the adjusted $\boldsymbol{R}^{2}$ figure along the years indicate improvements in value relevance of the financial data, improvements in earnings quality, and increases in earnings management practices, while reduction in the $\boldsymbol{R}^{2}$ figure entail decreases in value relevance, earnings quality and earnings management practices.

\section{RESULTS AND DISCUSSIONS}

Table 1 shows the descriptive statistics of the variables used in the analysis. The table shows that between the years under consideration, the average stock price of all the companies utilised in the study was about 15.75 . The measure of earnings quality and earnings management however maintained an overall negative average with total accruals having a mean of -

224,853 , while discretionary accruals maintained a mean of -0.002 . All the independent variables utilised (PAT, BVE, NOSH, EBIT, OCF, REV, PPE, and WC) however, maintained positive averages.

Discretionary accruals (DACC) displayed the lowest degree of volatility with standard deviation of 0.026 , while revenue (REV) exhibited the highest degree of volatility, with a standard deviation of 36,286,722. Most of the variables were skewed to the right, with the exception of total accruals (ACCR), discretionary accruals (DACC) and earnings before interest and tax (EBIT), which were negatively skewed. Also, all the variables used in the study are normally distributed as observed from the Jarque-Bera statistics.

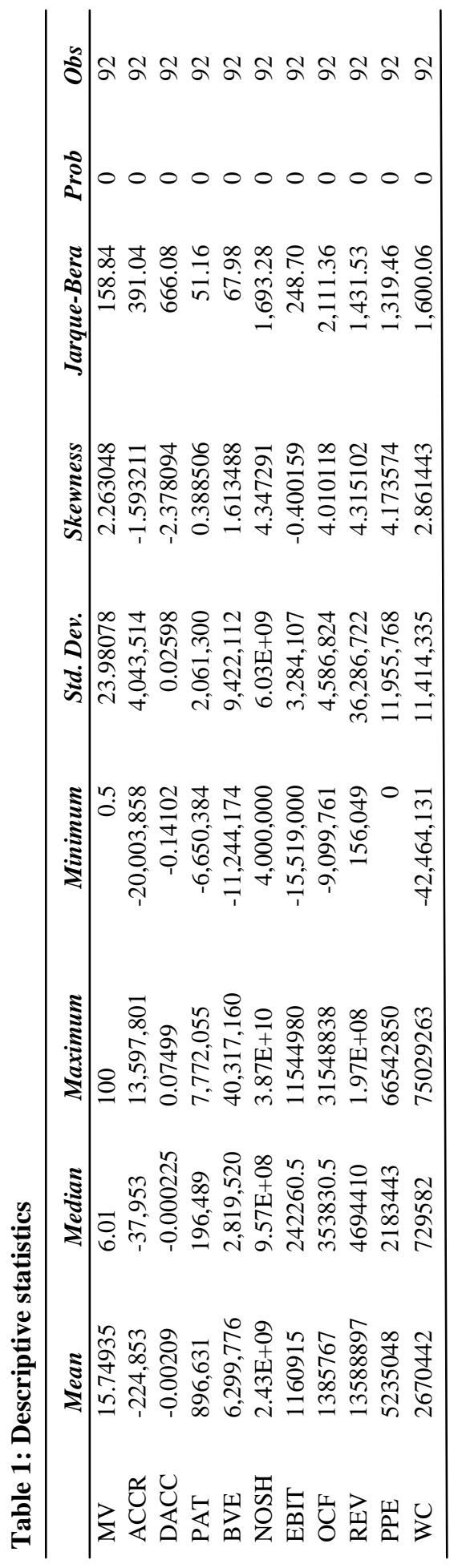


The hypotheses for the study are tested using the regression analysis. The models are constructed such that the dependent variables capture the value relevance, earnings quality and earnings management of the accounting information contained in the financial statements, while the independent variables jointly combine to explain the degree of variations in financial reporting quality for the respective period. The variations in the reporting quality are captured by fluctuations in the explanatory power of the independent variables; captured by the $\boldsymbol{R}^{2}$ statistics.

Hypothesis one is analysed using Table 2 (preIFRS) and table 3 (post-IFRS). The adjusted $\boldsymbol{R}^{2}$ statistics of table 2 indicates that about $5 \%$ of the total systematic variations in the value relevance of the accounting information is explained by a combination of the independent variables. This statistics increases to about $17 \%$ post-IFRS period measured by the same variables as outlined in Table 3. This means that adoption of IFRS in Nigeria has led to significant improvements in the value relevance of financial information; thereby enhancing the quality of financial reporting.

Hypothesis two is analysed using table 4 (preIFRS) and table 5 (post-IFRS). The adjusted $\boldsymbol{R}^{2}$ statistics increased from about $28 \%$ before the adoption of IFRS (table 4) to about $79 \%$ after the adoption of IFRS (table 5). This reveals that the quality of reported earnings improves postIFRS adoption; hence, an improvement in the quality of financial reporting after the adoption of IFRS.

Hypothesis three is analysed using table 6 (preIFRS) and table 7 (post-IFRS). The adjusted $\boldsymbol{R}^{2}$ statistics of table 6 indicates that about $76 \%$ of the total systematic variations in the existence of earnings management practices (represented by the extent of discretionary accruals), is captured by the totality of the independent variables. This statistics decreases to about $59 \%$

Table 2: Value Relevance pre-IFRS

Dependent Variable: MV

Method: Panel Least Squares

Sample: 2010-2011

\begin{tabular}{ccllc}
\hline \multicolumn{1}{r}{ Variable } & Coefficient & \multicolumn{1}{c}{ Std. Error } & t-Statistic & Prob. \\
\hline & & & \\
C & 13.01884 & 3.819480 & 3.408538 & 0.0015 \\
PAT & $3.31 \mathrm{E}-06$ & $2.35 \mathrm{E}-06$ & 1.408767 & 0.1663 \\
BE & $-7.42 \mathrm{E}-08$ & $6.18 \mathrm{E}-07$ & -0.120044 & 0.9050 \\
NOSH & $-7.77 \mathrm{E}-10$ & $6.18 \mathrm{E}-10$ & -1.257619 & 0.2155 \\
& & & \\
R-squared & & & \\
Adjusted R-squared & 0.109574 & Mean dependent var & \\
S.E. of regression & 0.045972 & S.D. dependent var & \\
Sum squared resid & 20.91831 & Akaike info criterion & & 21.41639 \\
Log likelihood & 18378.19 & Schwarz criterion & 9.002068 \\
F-statistic & -203.0476 & Hannan-Quinn criter. & \\
Prob(F-statistic) & 1.722815 & Durbin-Watson stat & \\
\hline
\end{tabular}

Journal of Science and Technology ㄷ KNUST December 2015 
Table 3: Value relevance post-IFRS

Dependent Variable: MV

Method: Panel Least Squares

Sample: 2012-2013

\begin{tabular}{lcccc}
\hline Variable & Coefficient & Std. Error & t-Statistic & Prob. \\
\hline & & & \\
C & 13.98842 & 4.344086 & 3.220106 & 0.0025 \\
PAT & $4.25 \mathrm{E}-06$ & $2.47 \mathrm{E}-06$ & 1.722705 & 0.0923 \\
BE & $2.67 \mathrm{E}-07$ & $5.48 \mathrm{E}-07$ & 0.487138 & 0.6287 \\
NOSH & $-9.00 \mathrm{E}-10$ & $6.24 \mathrm{E}-10$ & -1.443626 & 0.1563 \\
& & & \\
R-squared & & & \\
Adjusted R-squared & 0.224717 & Mean dependent var & & 18.12043 \\
S.E. of regression & 23.169340 & S.D. dependent var & & 26.32071 \\
Sum squared resid & 24169.51 & Akaike info criterion & & 9.275996 \\
Log likelihood & -209.3479 & Schwarz criterion & & 9.435008 \\
F-statistic & 4.057922 & Dannan-Quinn criter. & & 1.3585610 \\
Prob(F-statistic) & 0.012779 & Durbin-Watson stat & \\
\hline
\end{tabular}

Table 4: Earnings quality pre-IFRS

Dependent Variable: ACCR

Method: Panel Least Squares

Sample: 2012-2013

\begin{tabular}{|c|c|c|c|c|}
\hline Variable & Coefficient & Std. Error & t-Statistic & Prob. \\
\hline $\mathrm{C}$ & 213162.4 & 530945.2 & 0.401477 & 0.6901 \\
\hline $\mathrm{OCF}$ & -0.694267 & 0.258028 & -2.690660 & 0.0102 \\
\hline REV & 0.040092 & 0.078256 & 0.512322 & 0.6111 \\
\hline PPE & -0.057239 & 0.231102 & -0.247677 & 0.8056 \\
\hline R-squared & 0.331405 & Mean dependent var & & -382023.1 \\
\hline Adjusted R-squared & 0.283648 & S.D. dependent var & & 3795879. \\
\hline S.E. of regression & 3212740. & Akaike info criterion & & 32.88609 \\
\hline Sum squared resid & $4.34 \mathrm{E}+14$ & Schwarz criterion & & 33.04510 \\
\hline Log likelihood & -752.3800 & Hannan-Quinn criter. & & 32.94565 \\
\hline F-statistic & 6.939434 & Durbin-Watson stat & & 1.410651 \\
\hline Prob(F-statistic) & 0.000674 & & & \\
\hline
\end{tabular}


Table 5: Earnings quality post-IFRS

Dependent Variable: ACCR

Method: Panel Least Squares

Sample: 2012-2013

\begin{tabular}{lclcc}
\hline \multicolumn{1}{c}{ Variable } & Coefficient & Std. Error & t-Statistic & Prob. \\
\hline & & & \\
OCF & -1.138076 & 0.110692 & -10.28151 & 0.0000 \\
REV & 0.053771 & 0.039137 & 1.373913 & 0.1766 \\
PPE & 0.074415 & 0.102604 & 0.725264 & 0.4722 \\
& & & \\
R-squared & & & -67682.02 \\
Adjusted R-squared & 0.794172 & Mean dependent var & & 4313251. \\
S.E. of regression & 0.784598 & S.D. dependent var & & 31.92002 \\
Sum squared resid & 2001840. & Akaike info criterion & & 32.03928 \\
Log likelihood & $1.72 \mathrm{E}+14$ & Schwarz criterion & & 31.96470 \\
Durbin-Watson stat & -731.1606 & Hannan-Quinn criter. & & \\
\hline
\end{tabular}

Table 6: Earnings management pre-IFRS

Dependent Variable: DACC

Method: Panel Least Squares

Sample: 2010-2011

\begin{tabular}{|c|c|c|c|c|}
\hline Variable & Coefficient & Std. Error & t-Statistic & Prob. \\
\hline $\mathrm{C}$ & 0.000657 & 0.002409 & 0.272637 & 0.7865 \\
\hline REV & $-3.34 \mathrm{E}-10$ & $2.91 \mathrm{E}-10$ & -1.145261 & 0.2587 \\
\hline PPE & $-8.72 \mathrm{E}-10$ & $8.60 \mathrm{E}-10$ & -1.013550 & 0.3167 \\
\hline WC & $-6.02 \mathrm{E}-11$ & $2.97 \mathrm{E}-10$ & -0.202740 & 0.8403 \\
\hline EBIT & $5.74 \mathrm{E}-09$ & $6.80 \mathrm{E}-10$ & 8.452245 & 0.0000 \\
\hline R-squared & 0.778431 & Mean dependent var & & -0.002947 \\
\hline Adjusted R-squared & 0.756815 & S.D. dependent var & & 0.024355 \\
\hline S.E. of regression & 0.012011 & Akaike info criterion & & -5.903741 \\
\hline Sum squared resid & 0.005914 & Schwarz criterion & & -5.704975 \\
\hline Log likelihood & 140.7860 & Hannan-Quinn criter. & & -5.829282 \\
\hline F-statistic & 36.01103 & Durbin-Watson stat & & 2.243232 \\
\hline Prob(F-statistic) & 0.000000 & & & \\
\hline
\end{tabular}


Table 7: Earnings management post-IFRS

Dependent Variable: DACC

Method: Panel Least Squares

Sample: 2012-2013

\begin{tabular}{|c|c|c|c|c|}
\hline Variable & Coefficient & Std. Error & $\mathrm{t}$-Statistic & Prob. \\
\hline $\mathrm{C}$ & -0.003701 & 0.003538 & -1.045980 & 0.3017 \\
\hline REV & $-1.46 \mathrm{E}-09$ & $3.05 \mathrm{E}-10$ & -4.791581 & 0.0000 \\
\hline PPE & $2.13 \mathrm{E}-09$ & $9.37 \mathrm{E}-10$ & 2.270467 & 0.0285 \\
\hline WC & $-1.14 \mathrm{E}-10$ & $4.27 \mathrm{E}-10$ & -0.266787 & 0.7910 \\
\hline EBIT & $7.14 \mathrm{E}-09$ & $2.43 \mathrm{E}-09$ & 2.942414 & 0.0053 \\
\hline R-squared & 0.629312 & Mean dependent var & & -0.001234 \\
\hline Adjusted R-squared & 0.593148 & S.D. dependent var & & 0.027754 \\
\hline S.E. of regression & 0.017703 & Akaike info criterion & & -5.127885 \\
\hline Sum squared resid & 0.012849 & Schwarz criterion & & -4.929120 \\
\hline Log likelihood & 122.9414 & Hannan-Quinn criter. & & -5.053427 \\
\hline F-statistic & 17.40131 & Durbin-Watson stat & & 2.082163 \\
\hline Prob(F-statistic) & 0.000000 & & & \\
\hline
\end{tabular}

Table 8: Summary of hypothesis test

\begin{tabular}{|c|c|c|c|c|}
\hline Measure of FRQ & $R^{2}$ pre-IFRS & $R^{2}$ post-IFRS & Decision Criteria & $\begin{array}{l}\text { Impact on Financial } \\
\text { Reporting Quality } \\
\text { (FRQ) }\end{array}$ \\
\hline Value Relevance & $5 \%$ & $17 \%$ & Reject $\mathbf{H o}_{1}$ & Improves FRQ \\
\hline Earnings Quality & $28 \%$ & $79 \%$ & Reject $\mathbf{H o}_{2}$ & Improves FRQ \\
\hline Earnings Management & $76 \%$ & $59 \%$ & Reject $\mathrm{Ho}_{3}$ & Improves FRQ \\
\hline
\end{tabular}

post-IFRS (table 7) period measured by the same variables. This entails that the adoption of IFRS in Nigeria has led to a decline in the execution of earnings management practices by corporations, thereby enhancing the quality of financial reporting.

Hence for all proxies utilised, an increase in financial reporting quality was observed for the relevant years. A summary of the results of each hypothesis is outlined in table 8 .

The study reveals that the adoption of IFRS in Nigeria led to improvements in the value relevance of accounting information contained in the financial statements. This finding supports the tenet of IFRS being viewed as a financial reporting system supported by strong govern- 
ance, sound regulatory framework and high quality standards that improves the overall quality of financial reporting. The result of improvements of financial reporting quality in terms of value relevance was in consonance with the work of Palea (2013); which concluded on the improvement of financial reporting quality after the adoption of IFRS based on a meta-analysis. The finding is also in agreement with the works of Muller (2014), Kargin (2013), Lin et al. (2012), and Paglietti (2009). The result was however in contrast with the findings of Garanina and Kormiltseva (2013) which found no evidence of increased value relevance of accounting data to external users of financial information.

The results of the study also confirmed that there is a statistically significant increase in the quality of earnings after the adoption of IFRS in Nigeria. This was represented by a massive increase in the adjusted $\boldsymbol{R}^{2}$ figure from $28 \%$ before the adoption of IFRS to $79 \%$ after the adoption of IFRS. The finding of the study was in agreement with the works of Ismail et al. (2013), Sellami and Fakhfakh (2013), Assidi and Omri (2012) and Sun et al. (2011). The findings of Ames (2013), Nullah (2013) and Hoque et al. (2012) however stipulated that IFRS adoption does not lead to increased earnings quality.

The study also revealed that earnings management significantly reduced in the post-IFRS period. Studies that portrayed similar results include those of Dimitropoulos et al. (2013), Karampinis and Hevas (2013), Marra et al. (2011), and Liu et al. (2011). Some studies also had contrary findings to that of the study. Ahmed et al. (2013) in their meta-analysis found that discretionary accruals did not reduce postIFRS adoption, while Doukakis (2013) found that mandatory IFRS adoption had no significant impact on either real or accrual based earnings management practices.

\section{CONCLUSION}

IFRS is driving the revolutionary world of ac- counting with over 120 countries either requiring or permitting its use. Organisations must fully understand benefits and challenges of the adoption in order to enhance their implementation and utilisation of the standards. Hence, professionals must be prepared to 'learn, unlearn and relearn' in order to minimise any negative impact, while maximising the benefits associated with IFRS adoption in the short, medium and long term (Omoye and Aderin, 2014).

The need to ascertain the effectiveness of the adoption of IFRS in enhancing the quality of financial reporting forms the crux of this research. Through an understanding of this, the study therefore sets out to analyse the overall effectiveness of the adoption of these standards in enhancing value relevance, earnings quality, and reducing the extent of earnings management practices.

The results of the study reveal that the adoption of IFRS has overall benefits in terms of improving the quality of reported financial information. It can also be concluded that the adoption of IFRS will have significant prospects as well as challenges on the activities of stakeholders. Specifically the benefits that would be derived from the adoption of IFRS as gleaned from our study indicate that IFRS on the overall would enhance financial reporting quality while reducing the probability of earnings management practices. This shows that IFRS adoption could be beneficial in the long run to the Nigerian financial landscape.

\section{REFERENCES}

Ahmed, K., Chalmers, K. and Khlif, H. (2013). A meta-analysis of IFRS adoption effects. The International Journal of Accounting, 48 (1), 173-217.

Ames, D. (2013). IFRS adoption and accounting quality: The case of South Africa. Journal of Applied Economics and Business Research, 3(3), 154-165. 


\section{Aderin and Otakefe}

Assidi, S. and Omri, M. A. (2012). IFRS and information quality: Cases of CAC $40 \mathrm{com}-$ panies. Global Journal of Management and Business Research, 12(19), 73-84.

Athanasios, V., Antonios, S., Ioannis, S. and Stergios, A. (2013). The effect of the IFRS on intercompany transactions: The case of the Greek food-beverage sector. Procedia Technology, 8(1), 360-370.

Dimitropoulos, P. E., Asteriou, D., Kousenidis, D. and Leventis, S. (2013). The impact of IFRS on accounting quality: Evidence from Greece. Advances in Accounting incorporating Advances in International Accounting, 30 (1), 1-15.

Doukakis, L. C. (2013). The effect of mandatory IFRS adoption on real and accrual based earnings management activities. Journal of Accounting and Public Policy, 32(1), 27-40.

Garanina, T. A. and Kormiltseva, P. S. (2013). The effect of international financial reporting standards (IFRS) adoption on the value relevance of financial reporting: A case of Russia. Research in Accounting in Emerging Economies, 13(1), 27-60.

He, X., Wong, T. J. and Young, D. (2009). Challenges for implementation of fair value accounting in emerging markets: Evidence from IFRS adoption in China. Retrieved from http://www.tippie.uiowa.edu/accounting/ mcgladrey/pdf/wong_tj.pdf on 31st March, 2015.

Hoque, M. N., Zijl, T. V., Dunstan, K. and Karim, W. (2012). The effect of IFRS adoption and investor protection on earnings quality around the world. The International Journal of Accounting, 47(1), 333-355.

Iatridis, G. and Rouvolis, S. (2010). The postadoption effects of the implementation of international financial reporting standards in Greece. Journal of International Auditing and Taxation, 19(1), 55-65.

Ismail, W. A., Kamarudin, K. A., Zijl, T. and Dunstan, K. (2013). Earnings quality and the adoption of IFRS based accounting standards: Evidence from an emerging market. Asian Review of Accounting, 21(1), 53-73.

Jeanjean, T. and Stolowy, H. (2008). Do accounting standard matter: An exploratory analysis of earnings management before and after IFRS adoption. Journal of Accounting and Public Policy, 27(1), 480-494.

Karampinis, N. I. and Hevas, D. L. (2013). Effects of IFRS adoption on tax-induced incentives for financial earnings management: Evidence from Greece. The International Journal of Accounting, 48(1), 218-247.

Kargin, S. (2013). The impact of IFRS on the value relevance of accounting information: Evidence from Turkish Firms. International Journal of Economics and Finance, 5(4), 71 80 .

Lin, C., Hua, C., Lin, W. and Lee, W. (2012). IFRS adoption and financial reporting: Taiwan experience. International Journal of Academic Research in Accounting, Finance and Management Sciences, 2(4), 285-294.

Liu, C., Yao, L. J., Hu, N. and Liu, L. (2011). The impact of IFRS on accounting quality in a regulated market: An empirical study of China. Journal of Accounting, Auditing and Finance, 26(4), 659-676.

Madawaki, A. (2012). Adoption of international financial reporting standards in developing countries: The case of Nigeria. International Journal of Business and Management, 7(3), 152-161.

Marra, A., Mazzola, P. and Prencipe, A. (2011). Board monitoring and earnings management: Pre and post IFRS. The International Journal of Accounting, 46(1), 205-230. 
IFRS adoption and financial reporting... 83

Muller, V. O. (2014). The impact of IFRS adoption on the quality of consolidated financial reporting. Procedia - Social and Behavioural Sciences, 109(1), 976-982.

Nullah, Y. M. (2013). IFRS adoption in research and development companies. Journal of Administrative Sciences and Policy Studies, 1(1), 34-48.

Omoye, A. S. and Aderin, A. (2014). IFRS adoption in developing economies: The case of Nigeria. The Certified National Accountant, 22(2), 19-25.

Outa, E. R. (2011). The impact of international financial reporting standards (IFRS) adoption on the accounting quality of listed companies in Kenya. International Journal of Accounting and Financial Reporting, 1(1), 212-241.

Paglietti, P. (2009). Investigating the effects of the EU mandatory adoption of IFRS on accounting quality: Evidence from Italy. International Journal of Business and Management, 4(12), 3-18.

Palea, V. (2013). IAS/IFRS and financial reporting quality: Lessons from European experience. China Journal of Accounting Research, 6(1), 247-263.

Sellami, M. and Fakhfakh, H. (2013). Effect of the mandatory adoption of IFRS on real and accrual based earnings management: Empirical evidence from France. International Journal of Accounting and Economic Studies, 2(1), 22-33.

Sun, J., Cahan, S. F. and Emmanuel, D. (2011). How would the mandatory adoption of IFRS affect the earnings quality of U.S. firms: Evidence from cross-listed firms in the U.S. Accounting Horizons, 25(4), 837-860. 